\title{
Preparation of mesoporous Fe-Cu mixed metal oxide nanopowder as active and stable catalyst for low-temperature CO oxidation
}

\author{
Ehsan Amini, Mehran Rezaei * \\ Institute of Nanoscience and Nanotechnology, Catalyst and Advanced Materials Research Laboratory, Chemical Engineering Department, Faculty of \\ Engineering, University of Kashan, Kashan, Iran
}

A R T I C L E I N F 0

Article history:

Received 13 April 2015

Accepted 25 May 2015

Published 20 October 2015

\section{Keywords:}

Iron oxide

Copper oxide

Metal oxide catalyst

Mesoporous nanopowder

CO oxidation

Sol-gel method

\section{Introduction}

There is a growing need for low-temperature CO oxidation catalysts with high stabilities and activities because of their numerous applications, e.g., in air purification devices for respiratory protection, $\mathrm{CO}_{2}$ lasers, pollution control devices for reducing environmental and industrial emissions, and $\mathrm{CO}$ gas sensors, and for removal of CO from enclosed atmospheres such as those in space craft and submarines [1]. Noble metals (e.g., $\mathrm{Au}, \mathrm{Pt}, \mathrm{Ru}$, and $\mathrm{Pd}$ ) promoted with or supported on reducible oxides such as $\mathrm{Fe}_{2} \mathrm{O}_{3}, \mathrm{CeO}_{2}, \mathrm{MnO}_{2}, \mathrm{SnO}_{2}$, and $\mathrm{TiO}_{2}$ are the best candidates for low-temperature $\mathrm{CO}$ oxidation, and they are able to remove $\mathrm{CO}$ completely at ambient temperature [1-7]. However, noble metals are prone to sulfur poisoning and are expensive, therefore attention is increasingly being focused on the preparation of cheap transition-metal oxide catalysts such as $\mathrm{CuO}, \mathrm{Co}_{3} \mathrm{O}_{4}$, and $\mathrm{MnO}_{2}$ [8-16].

The catalytic activities of transition-metal oxides are lower than those of noble metals. In recent years, the application of nanoscience and nanotechnology in catalysis and the development of catalyst synthetic methods have led to improvements in the activities, selectivities, and stabilities of catalysts. Control of the nanoparticle shape and size and the use of nanoparticles with high surface areas as catalysts enable transition-metal oxide catalysts to be used instead of noble-metal catalysts.

Generally, transition-metal oxide nanoparticles are synthesized via chemical methods, using a series of surfactants containing groups such as amine and phosphorous groups to control the particle shape and size. These surfactants may not be removed entirely by calcination; they can remain on the catalyst surface and cover some of the active sites on the catalyst, and this has a negative effect on the catalytic properties

* Corresponding author. Tel: +98-31-55912469; Fax: +98-31-55559930; E-mail: rezaei@kashanu.ac.ir

DOI: 10.1016/S1872-2067(15)60922-6 | http://www.sciencedirect.com/science/journal/18722067 | Chin. J. Catal., Vol. 36, No. 10, October 2015 
$[17,18]$. Avoidance of the use of surfactants in nanoparticle preparation is therefore important. In recent years, much attention has been focused on the synthesis of nanoparticles with high surface areas, using surfactant-free methods.

Among transition-metal oxides, iron oxide is an attractive candidate because it is cheap and efficient, especially in the removal of $\mathrm{CO}$ in burning cigarettes. The potential toxicity of other catalysts is a challenge. Furthermore, they have dual functions, based on their redox behavior in the presence of oxygen, and lattice oxygen loss in the absence of oxygen.

However, pure $\mathrm{Fe}_{2} \mathrm{O}_{3}$ has poor catalytic activity for $\mathrm{CO}$ oxidation at low temperature. Structural modifications of the $\mathrm{Fe}_{2} \mathrm{O}_{3}$ lattice by doping with copper oxide improve the catalytic activity of $\mathrm{Fe}_{2} \mathrm{O}_{3}$ at low temperatures $[8,9]$.

In our previous work [19], we reported the synthesis of $\mathrm{Fe}-\mathrm{Cu}$ mixed metal oxide nanopowders via a sol-gel route using propylene oxide as a gelation agent and $\mathrm{FeCl}_{3} \cdot 6 \mathrm{H}_{2} \mathrm{O}$ as the $\mathrm{Fe}$ precursor in aqueous solution. $\mathrm{CO}$ oxidation reactions over the synthesized nanopowders were investigated in detail. The results showed that moderate catalytic activity was achieved in low-temperature $\mathrm{CO}$ oxidation.

Epoxides are cyclic ethers, and they are much more reactive than simple ethers because of ring strain. Epoxides are used as acid scavengers in organic synthesis. They act as a proton scavenger through protonation of the epoxide oxygen, and then irreversible ring opening by nucleophilic attack of an anionic conjugate base. This process is shown in Eq. (1):

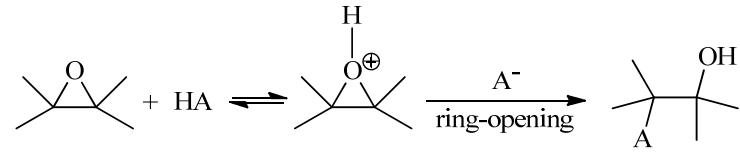

The aqua ion $\left[\mathrm{Fe}\left(\mathrm{H}_{2} \mathrm{O}\right)_{6}\right]^{3+}$ is a strong acid, and epoxides can be easily protonated by strong acids. Propylene oxide therefore consumes protons from the hydrated Fe(III) species, as shown in Eq. (2):

$$
\stackrel{\mathrm{O}}{\mathrm{C}_{\mathrm{CH}_{3}}}+\mathrm{Fe}\left(\mathrm{H}_{2} \mathrm{O}\right)_{6}{ }^{3+} \rightleftharpoons \Delta_{\mathrm{CH}_{3}}^{\mathrm{O}}+\mathrm{Fe}(\mathrm{OH})\left(\mathrm{H}_{2} \mathrm{O}\right)_{5}{ }^{2+}
$$

The Fe(III) complex on the right-hand side of Eq. (2) can undergo further hydrolysis and condensation to form more-condensed Fe(III) oxide species, as shown in Eq. (3):

$$
2 \mathrm{Fe}(\mathrm{OH})\left(\mathrm{H}_{2} \mathrm{O}\right)_{5}{ }^{2+} \rightleftharpoons\left[\left(\mathrm{H}_{2} \mathrm{O}\right)_{5} \mathrm{Fe}-\mathrm{O}-\mathrm{Fe}\left(\mathrm{H}_{2} \mathrm{O}\right)_{5}\right]^{4+}+\mathrm{H}_{2} \mathrm{O}
$$

The protons generated in these reactions are consumed by protonation of the epoxide. The protonated epoxide can then be irreversibly ring opened via nucleophilic attack by $\mathrm{Cl}^{-}$in solution. This process is shown in Eq. (4):

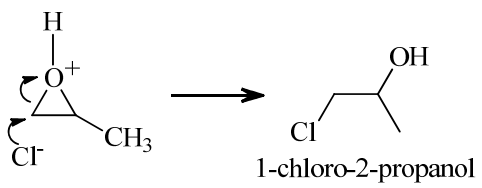

This process leads to elimination of protons from solution and causes further hydrolysis of the Fe(III) complex, leading to formation of a monolithic gel.

$\mathrm{Cl}^{-}$ions adversely affect catalytic performances [20]. There was no washing step to remove $\mathrm{Cl}^{-}$ions in our sol-gel method.
Furthermore, $\mathrm{Cl}^{-}$ions are not removed by catalyst calcination, therefore they remain on the catalyst surface and cover some active sites, leading to decreased catalytic activity.

Here, we report the preparation of mesoporous Fe-Cu mixed metal oxide nanopowders with different $\mathrm{Cu} / \mathrm{Fe}$ molar ratios using $\mathrm{Fe}\left(\mathrm{NO}_{3}\right)_{3} \cdot 9 \mathrm{H}_{2} \mathrm{O}$ as the Fe precursor. However, based on the mechanism of gel formation when $\mathrm{Fe}\left(\mathrm{NO}_{3}\right)_{3} \cdot 9 \mathrm{H}_{2} \mathrm{O}$ is used as the Fe precursor, we cannot use water as the solvent. This is because, under the same conditions, water is a better nucleophile than the nitrate ion, therefore the protonated species in Eq. (2) could be preferentially ring opened by water. This leads to the proposed scenario shown in Eq. (5):

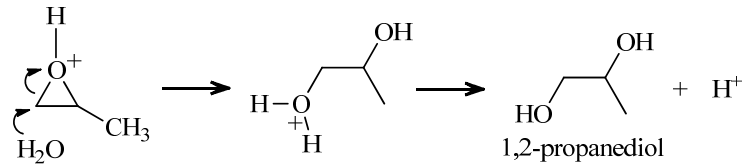

Here, the water attacks a ring carbon and is then deprotonated to give 1,2-propanediol and regenerate a proton. A proton is regenerated, therefore a gel is not formed.

In this work, we therefore used ethanol as the solvent and $\mathrm{Fe}\left(\mathrm{NO}_{3}\right)_{3} \cdot 9 \mathrm{H}_{2} \mathrm{O}$ as the Fe precursor for the preparation of mesoporous $\mathrm{Fe}-\mathrm{Cu}$ mixed metal oxide nanopowders with different $\mathrm{Cu} / \mathrm{Fe}$ molar ratios and high specific surface areas. The method is a simple, inexpensive, and surfactant-free sol-gel route. In addition, low-temperature $\mathrm{CO}$ oxidation over the prepared samples was investigated in detail. The effects of the $\mathrm{Cu} / \mathrm{Fe}$ molar ratio, calcination temperature, and catalyst stability in the presence of water vapor and $\mathrm{CO}_{2}$ were also studied.

\section{Experimental}

\subsection{Materials}

$\mathrm{Fe}\left(\mathrm{NO}_{3}\right)_{3} \cdot 9 \mathrm{H}_{2} \mathrm{O}$ and $\mathrm{Cu}\left(\mathrm{NO}_{3}\right)_{2} \cdot 3 \mathrm{H}_{2} \mathrm{O}$ were used as the $\mathrm{Fe}$ and $\mathrm{Cu}$ precursors, respectively. Propylene oxide and absolute ethanol were used as the gelation agent and solvent, respectively. All the starting materials were used without further purification.

\subsection{Catalyst preparation}

Fe-Cu mixed metal oxide nanopowders with different $\mathrm{Cu} / \mathrm{Fe}$ molar ratios were synthesized via a simple sol-gel route using propylene oxide as a gelation agent. In a typical synthesis, $\mathrm{Fe}\left(\mathrm{NO}_{3}\right)_{3} \cdot 9 \mathrm{H}_{2} \mathrm{O}(10 \mathrm{mmol})$ and a calculated amount of $\mathrm{Cu}\left(\mathrm{NO}_{3}\right)_{2} \cdot 3 \mathrm{H}_{2} \mathrm{O}$ were dissolved in an appropriate amount of absolute ethanol at room temperature. After stirring for 15 min, a calculated amount of propylene oxide (propylene oxide $/(\mathrm{Fe}+\mathrm{Cu})$ molar ratio $=11)$ was added to the prepared solution. Gel formation occurred within $5 \mathrm{~min}$. The resulting gel was aged at room temperature for $1 \mathrm{~h}$, dried at $80{ }^{\circ} \mathrm{C}$ for $48 \mathrm{~h}$, and calcined at various temperatures, with a ramp rate of 3 ${ }^{\circ} \mathrm{C} / \mathrm{min}$, for $5 \mathrm{~h}$ in air. The nominal $\mathrm{CuO}$ contents were 10,15 , and $20 \mathrm{~mol} \%$, and the corresponding catalysts were denoted by $\mathrm{FeCu} 10, \mathrm{FeCu} 15$, and FeCu20, respectively.

\subsection{Catalyst characterization}


X-ray diffraction (XRD) was performed using a PANalytical X'Pert-Pro X-ray diffractometer with a $\mathrm{Cu} K_{\alpha}$ monochromatized radiation source and a $\mathrm{Ni}$ filter, in the scanning range $2 \theta=$ $20^{\circ}-80^{\circ}$. Temperature-programmed reduction $\left(\mathrm{H}_{2}-\mathrm{TPR}\right)$ was performed using an automatic instrument (Chemisorb 2750, Micromeritics) equipped with a thermal conductivity detector (TCD). In the TPR measurements, the catalyst (100 mg) was heated $\left(10{ }^{\circ} \mathrm{C} / \mathrm{min}\right)$ in a gas flow $(30 \mathrm{~mL} / \mathrm{min})$ containing a mixture of $\mathrm{H}_{2}: \operatorname{Ar}$ (10:90). Prior to the TPR experiments, the samples were heated in an inert atmosphere (Ar) at $200{ }^{\circ} \mathrm{C}$ for $1 \mathrm{~h}$. The $\mathrm{H}_{2}$ uptake during the reduction was measured using a TCD. Fourier-transform infrared (FTIR) spectroscopy (NEXus FTIR spectrophotometer) was performed using $\mathrm{KBr}$ pellets containing $1 \%$ by weight of the sample. The catalysts were examined using thermogravimetry (TG) and differential thermal analysis (DTA; Netzsch STA 409 system) at a heating rate of $10{ }^{\circ} \mathrm{C} / \mathrm{min}$ in a static air atmosphere. Nitrogen adsorption/desorption analysis (BET method) was performed at -196 ${ }^{\circ} \mathrm{C}$ using an automated gas adsorption analyzer (Tristar 3020, Micromeritics). Transmission electron microscopy (TEM) was performed using a JEM-2100UHR instrument.

\subsection{Catalytic activity tests}

Catalytic activity tests for $\mathrm{CO}$ oxidation were performed in a continuous-flow fixed-bed quartz reactor at ambient pressure. The reactor was charged with $100 \mathrm{mg}$ of the prepared catalyst sieved to 35-70 mesh. The reaction gases consisted of $20 \% \mathrm{O}_{2}$ and $2 \% \mathrm{CO}$, balanced with $78 \%$ inert gas. The catalysts were pretreated in $20 \% \mathrm{O}_{2}$ balanced with $\mathrm{He}$ at $300{ }^{\circ} \mathrm{C}$ for $2 \mathrm{~h}$ prior to the reaction. The activity tests were performed at different temperatures, in steps of $25^{\circ} \mathrm{C}$. The gas compositions of the reactants and products were analyzed on line using a gas chromatograph (Varian 3400) equipped with a TCD and a $5 \mathrm{~A}$ molecular sieve column. The CO conversion $\left(X_{\mathrm{CO}}\right)$ was obtained using Eq. (6):

$$
X_{\mathrm{CO}}=\left(\mathrm{CO}_{\text {inlet }}-\mathrm{CO}_{\text {outlet }}\right) / \mathrm{CO}_{\text {inlet }} \times 100 \%
$$

\section{Results and discussion}

\subsection{Catalyst characterization}

Fig. 1 and 2 show the XRD patterns of the sol-gel-prepared $\mathrm{Fe}-\mathrm{Cu}$ mixed metal oxide nanopowders with different $\mathrm{Cu} / \mathrm{Fe}$ molar ratios calcined at various temperatures. The pattern of the pure $\mathrm{Fe}_{2} \mathrm{O}_{3}$ sample shows the reflections characteristic of rhombohedral hematite $\left(\alpha-\mathrm{Fe}_{2} \mathrm{O}_{3}\right)$ and cubic maghemite $\left(\gamma-\mathrm{Fe}_{2} \mathrm{O}_{3}\right)$ iron oxide structures. The addition of $10 \mathrm{~mol} \% \mathrm{CuO}$ (FeCu10 sample) caused the diffraction peaks related to $\alpha-\mathrm{Fe}_{2} \mathrm{O}_{3}$ to disappear, and peaks from $\mathrm{CuFe}_{2} \mathrm{O}_{4}$ appeared. These changes in the peak positions suggest the incorporation of $\mathrm{Cu}$ atoms into the $\alpha-\mathrm{Fe}_{2} \mathrm{O}_{3}$ lattice and formation of spinel $\mathrm{CuFe}_{2} \mathrm{O}_{4}$. For FeCu15 and $\mathrm{FeCu} 20$, the corresponding diffraction patterns were similar to that of the FeCu10 sample. When the calcination temperature was increased to $400{ }^{\circ} \mathrm{C}$, the sample diffraction patterns did not change. However, on further increasing the calcination temperature, the characteristic peak for $\alpha-\mathrm{Fe}_{2} \mathrm{O}_{3}$

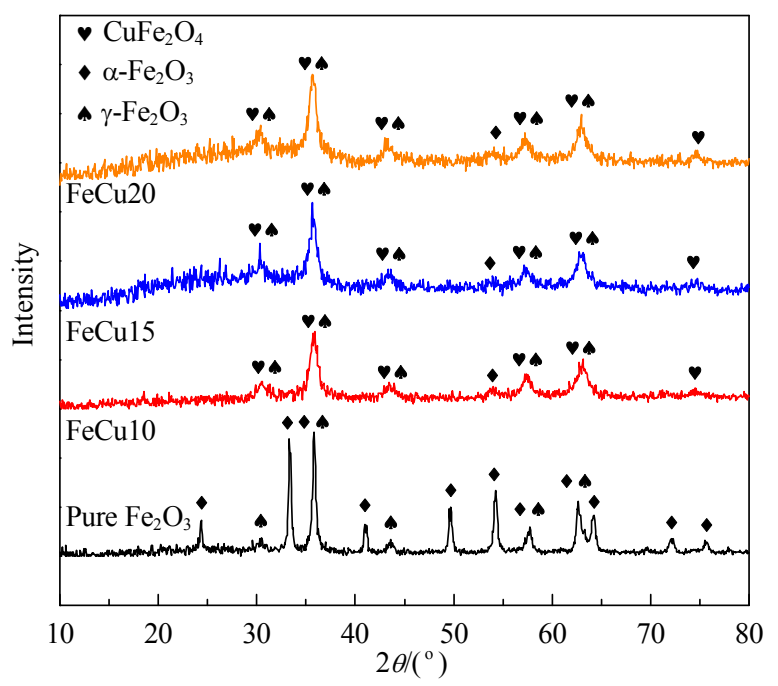

Fig. 1. XRD patterns of prepared $\mathrm{Fe}-\mathrm{Cu}$ mixed metal oxide nanopowders with different $\mathrm{Cu} / \mathrm{Fe}$ molar ratios, calcined at $300{ }^{\circ} \mathrm{C}$.

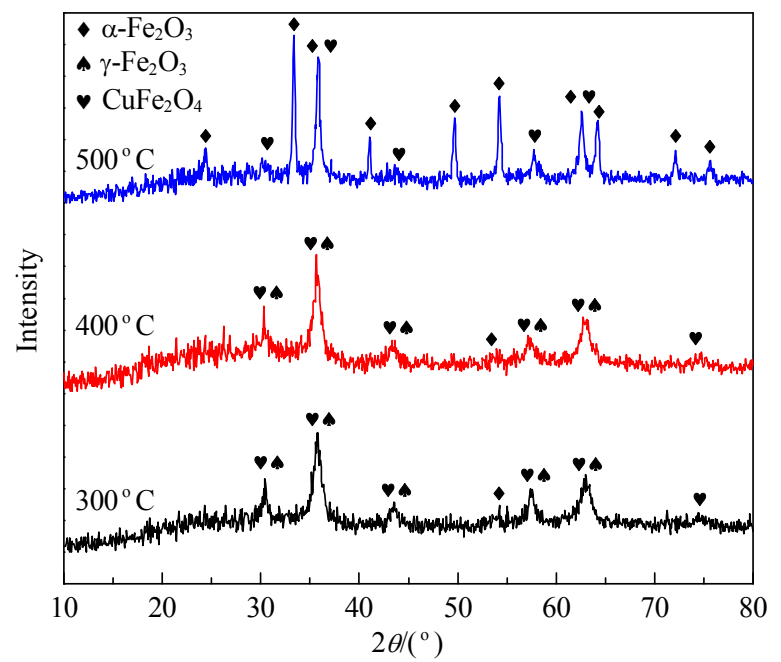

Fig. 2. XRD patterns of FeCu15 samples calcined at 300, 400, and $500^{\circ} \mathrm{C}$.

appeared. This indicates a phase transformation from $\gamma-\mathrm{Fe}_{2} \mathrm{O}_{3}$ to $\alpha-\mathrm{Fe}_{2} \mathrm{O}_{3}$.

The average crystallite sizes were calculated from the half-widths of the main diffraction peaks, using the Scherrer formula; the results are shown in Table 1.

The $\mathrm{H}_{2}$-TPR profiles of prepared catalysts with different $\mathrm{CuO}$ contents are shown in Fig. 3. The $\mathrm{H}_{2}$-TPR profile of pure $\mathrm{Fe}_{2} \mathrm{O}_{3}$ shows two identified reduction peaks. The first peak, at 300-400 ${ }^{\circ} \mathrm{C}$, corresponds to the reduction of $\mathrm{Fe}_{2} \mathrm{O}_{3}$ to $\mathrm{Fe}_{3} \mathrm{O}_{4}$, and the wide peak above $600{ }^{\circ} \mathrm{C}$ is related to the reduction of $\mathrm{Fe}_{3} \mathrm{O}_{4}$ to $\mathrm{FeO}$ and $\mathrm{Fe}(0)$ [21]. The reduction profile of the FeCu10 sample has a sharp peak at $200{ }^{\circ} \mathrm{C}$. This peak is related to the reduction of $\mathrm{CuO}$ to $\mathrm{Cu}(0)$ [22]. The peaks corresponding to the reduction of $\mathrm{Fe}_{2} \mathrm{O}_{3}$ to $\mathrm{Fe}(0)$ in the $\mathrm{FeCu} 10$ sample were shifted to lower temperature compared with those of pure $\mathrm{Fe}_{2} \mathrm{O}_{3}$. This peak position shift shows that $\mathrm{CuO}$ promoted the reduction of $\mathrm{Fe}_{2} \mathrm{O}_{3}$ at low temperatures. Further increases in the $\mathrm{CuO}$ content (FeCu15 and $\mathrm{FeCu} 20$ ) increased the intensity 
Table 1

Structural properties and catalytic activities of prepared catalysts.

\begin{tabular}{lcccccc}
\hline Sample & $\begin{array}{c}\text { Calcination } \\
\text { temperature } \\
\left({ }^{\circ} \mathrm{C}\right)\end{array}$ & $\begin{array}{c}\text { Average } \\
\text { crystalline } \\
\text { size }(\mathrm{nm})\end{array}$ & $\begin{array}{c}\text { Surface } \\
\text { area } \\
\left(\mathrm{m}^{2} / \mathrm{g}\right)\end{array}$ & $\begin{array}{c}\text { Pore } \\
\text { volume } \\
\left(\mathrm{cm}^{3} / \mathrm{g}\right)\end{array}$ & $\begin{array}{c}\text { Average } \\
\text { pore size } \\
(\mathrm{nm})\end{array}$ & $\begin{array}{c}T_{100} \\
\left({ }^{\circ} \mathrm{C}\right)\end{array}$ \\
\hline $\mathrm{Fe}_{2} \mathrm{O}_{3}$ & 300 & 14 & 90.1 & 0.18 & 8.0 & 285 \\
$\mathrm{FeCu} 10$ & 300 & 10 & 110.8 & 0.22 & 7.9 & 180 \\
$\mathrm{FeCu} 15$ & 300 & 8 & 124.5 & 0.21 & 6.7 & 170 \\
$\mathrm{FeCu} 20$ & 300 & 11 & 107.8 & 0.25 & 9.3 & 200 \\
$\mathrm{FeCu} 15$ & 400 & 15 & 84.7 & 0.18 & 8.7 & 185 \\
$\mathrm{FeCu} 15$ & 500 & 28 & 17.9 & 0.09 & 20.3 & 200 \\
\hline
\end{tabular}

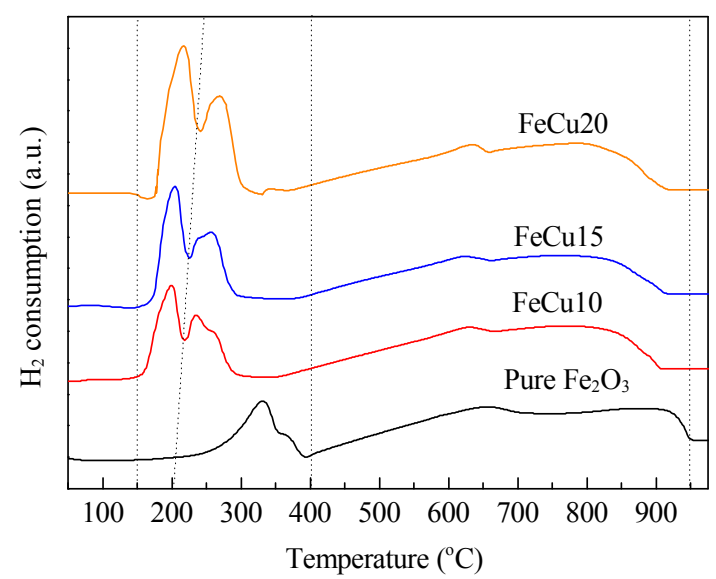

Fig. 3. $\mathrm{H}_{2}$-TPR profiles of prepared catalysts with various $\mathrm{CuO}$ contents, calcined at $300^{\circ} \mathrm{C}$.

of the peak related to $\mathrm{CuO}$ reduction.

Fig. 4 shows the FTIR spectra of the as-prepared and calcined FeCu15 samples. The wide peak in the as-prepared sample at $3395 \mathrm{~cm}^{-1}$ is ascribed to the stretching vibration of the hydroxyl groups of adsorbed water and ethanol; the peak intensity decreased after calcination. The weak band in this region in the spectrum of the calcined sample is related to adsorbed water. The peak at $1628.7 \mathrm{~cm}^{-1}$ is attributed to adsorbed water; the peak intensity decreased after calcination. The peak at $1081.9 \mathrm{~cm}^{-1}$ is ascribed to the $\mathrm{C}-0$ stretching vibration; it vanished after calcination. The two peaks at $\sim 2926.5$ $\mathrm{cm}^{-1}$ are attributed to the stretching vibrations of $\mathrm{CH}_{3}$ and $\mathrm{CH}_{2}$ groups in propylene oxide (and compounds derived from it during the sol-gel process); these peaks disappeared after cal-

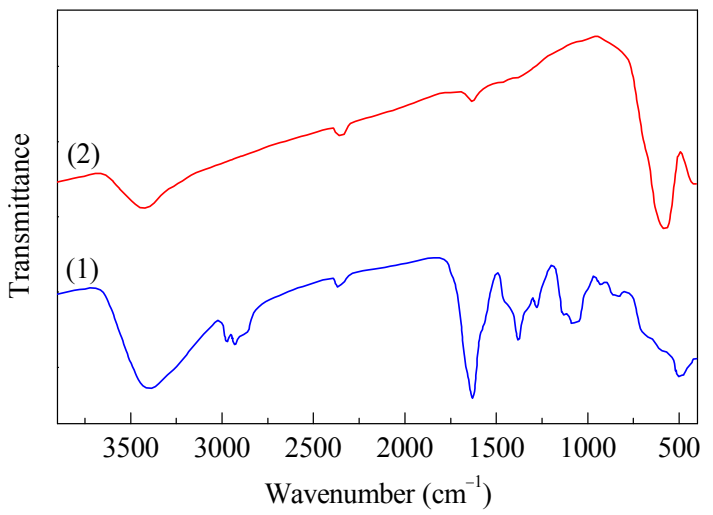

Fig. 4. FTIR spectra of as-prepared FeCu15 sample (1) and FeCu15 sample calcined at $300^{\circ} \mathrm{C}(2)$.

cination. The peak at $1377.2 \mathrm{~cm}^{-1}$, attributed to the bending vibration of $\mathrm{CH}_{3}$, also disappeared after calcination. The two peaks in the region $400-600 \mathrm{~cm}^{-1}$ are related to metal-oxygen bond vibrations at octahedral and tetragonal holes in the spinel structure; these peaks were sharpened by calcination at $300^{\circ} \mathrm{C}$.

Fig. 5 shows the TG-differential thermogravimetry (DTG) and DTA curves of the as-prepared FeCu15 sample. The DTA curve shows a broad endothermic peak in the region 50 to 150 ${ }^{\circ} \mathrm{C}$, related to mass losses in several step in the TG curve. These mass losses are related to the evaporation of water adsorbed on the surface and water trapped in the pores. An exothermic peak appears in the DTA curve at $150-250^{\circ} \mathrm{C}$, corresponding to a rapid mass loss in the TG curve. This exothermic peak is attributed to propylene oxide and its combustion products. There is an exothermic peak in the region $250-350{ }^{\circ} \mathrm{C}$, which is related to a weight loss in the TG curve in this region. This mass loss arises from removal of residual hydroxyl groups and crystallization of metal hydroxides to metal oxides. The weight loss from 350 to $450{ }^{\circ} \mathrm{C}$ in the TG curve, corresponding to the endothermic peak in the DTA curve in this region, is related to the decomposition of nitrate from the Fe and Cu precursors.

Fig. 6 shows the $\mathrm{N}_{2}$ adsorption/desorption isotherms and pore size distributions of the prepared catalysts, with different $\mathrm{CuO}$ loadings and calcined at various temperatures. The structural characteristics of all the samples are listed in Table 1.

The isotherms of all the samples are type IV, based on the

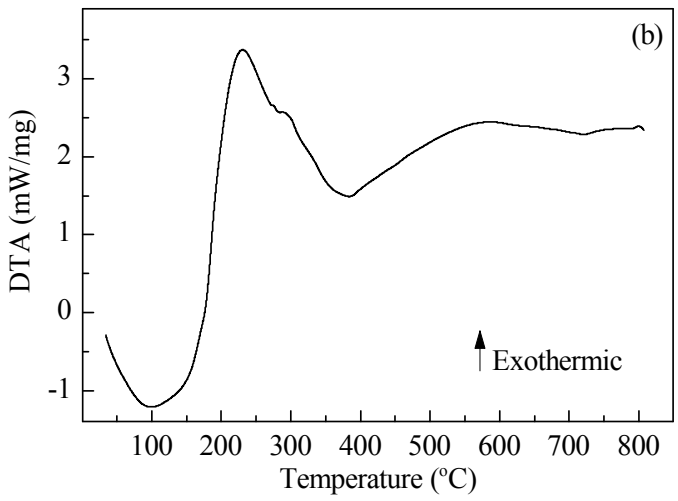

Fig. 5. TG-DTG (a) and DTA (b) curves of as-prepared FeCu15 catalyst. 

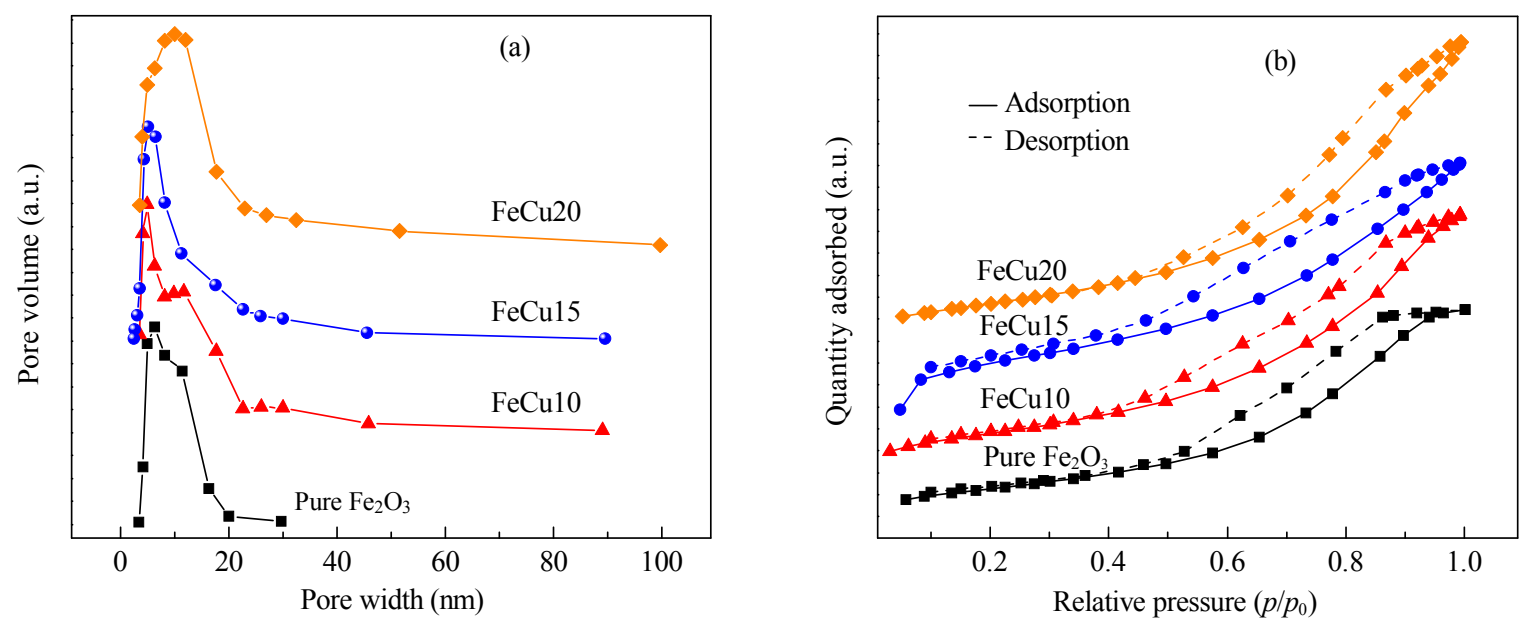

Fig. 6. Pore size distributions (a) and $\mathrm{N}_{2}$ adsorption/desorption isotherms (b) of all prepared catalysts calcined at $300{ }^{\circ} \mathrm{C}$.

International Union of Pure and Applied Chemistry classification scheme; this shows that they are mesoporous materials with complex structures made up of interconnected networks of different shapes and pore sizes. The hysteresis loops are type $\mathrm{H} 2$, which is characteristic of a solid containing particles crossed by nearly cylindrical channels, or consisting of agglomerated (unconsolidated) or aggregated (consolidated) spherical particles with nonuniform shapes or pore sizes. The pore size distribution curves show that samples with different $\mathrm{CuO}$ loadings calcined at $300{ }^{\circ} \mathrm{C}$ have mesoporous structures with narrow size distributions; this indicates good pore homogeneity. The pore size distributions of FeCu15 sample calcined at various temperatures are shown in Fig 7. The figure shows that with increasing calcination temperature, the pore sizes increase, accompanied by decreases in the surface areas. The pore walls collapse and form larger pores with increasing calcination temperature. The data in Table 1 show that the specific surface areas of all the samples calcined at $300{ }^{\circ} \mathrm{C}$ are higher than that of pure $\mathrm{Fe}_{2} \mathrm{O}_{3}\left(90.1 \mathrm{~m}^{2} / \mathrm{g}\right)$. In addition, with increasing CuO content up to $15 \mathrm{~mol} \%$, the specific surface area increases to $124.5 \mathrm{~m}^{2} / \mathrm{g}$. However, on increasing of the CuO loading to 20 mol\%, the specific surface area decreases. The results show that increasing the calcination temperature decreased the spe- cific surface area of the FeCu15 sample, as a result of pore destruction and particle sintering.

TEM images at different magnifications and electron diffraction pattern of FeCu15 calcined at $300{ }^{\circ} \mathrm{C}$ are shown in Fig. 8. The electron diffraction pattern shows several distinct concentric rings, indicating a polycrystalline structure. The TEM im-

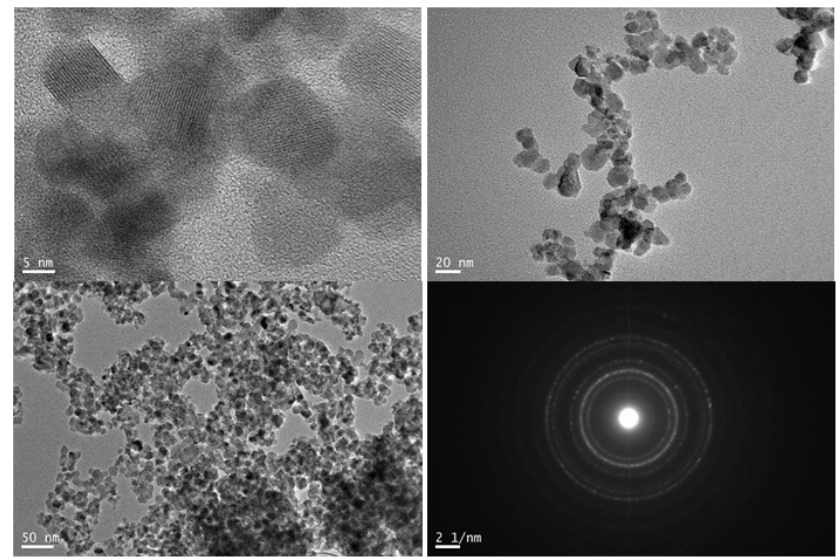

Fig. 8. TEM images at different magnifications and electron diffraction pattern of FeCu15 sample calcined at $300^{\circ} \mathrm{C}$.
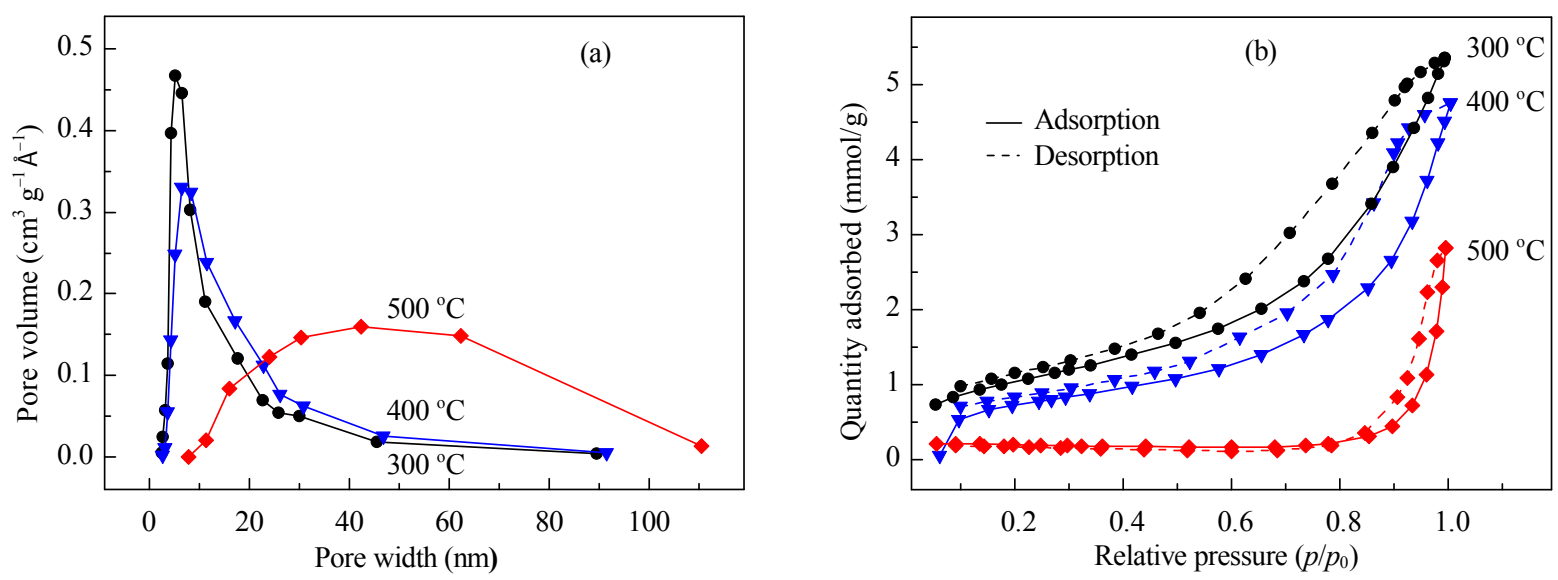

Fig. 7. Pore size distributions (a) and $\mathrm{N}_{2}$ adsorption/desorption isotherms (b) of FeCu15 sample calcined at 300,400 , and $500^{\circ} \mathrm{C}$. 


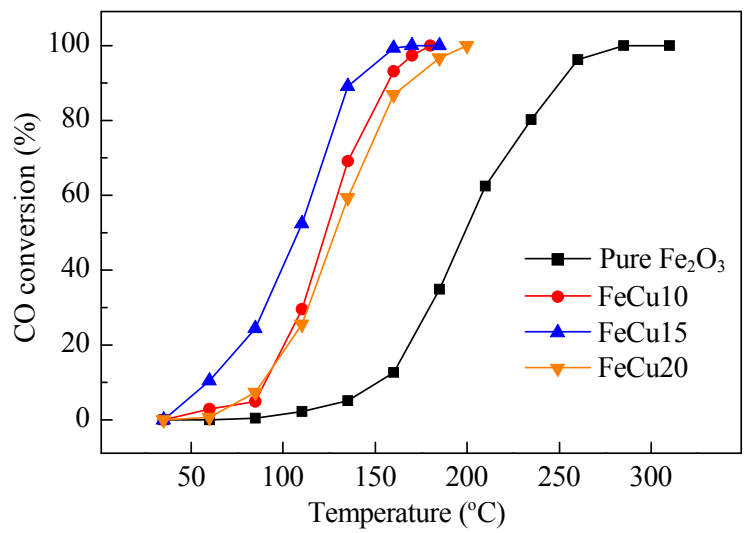

Fig. 9. Catalytic activities in $\mathrm{CO}$ oxidation over prepared catalysts with various $\mathrm{Cu} / \mathrm{Fe}$ molar ratios, calcined at $300^{\circ} \mathrm{C}$.

ages clearly show a nanocrystalline structure with particle sizes in the range $5-15 \mathrm{~nm}$.

\subsection{Catalytic activity tests}

Fig. 9 shows the CO conversions over prepared catalysts with various $\mathrm{CuO}$ contents, calcined at $300{ }^{\circ} \mathrm{C}$. The results show that the addition of $\mathrm{CuO}$ to $\mathrm{Fe}_{2} \mathrm{O}_{3}$ significantly increases the catalytic activity at low temperatures. $\mathrm{CuO}$ and pure $\mathrm{Fe}_{2} \mathrm{O}_{3}$ form Fe-Cu mixed metal oxides with high surface areas and catalytic activities through a synergistic effect. The FeCu15 sample had the highest surface area and catalytic activity, with total CO conversion at $170{ }^{\circ} \mathrm{C}$. However, the catalytic activity decreased with further increases in the $\mathrm{CuO}$ content. Excess $\mathrm{CuO}$ generally covers the catalyst surface and causes growth of $\mathrm{CuO}$ particles with low specific surface areas and catalytic activities.

Fig. 10 shows the $\mathrm{CO}$ oxidation curves for FeCu15 sample calcined at different temperatures. The catalytic activity decreased with increasing calcination temperatures. In general, with increasing calcination temperature, the pore walls are destroyed and larger pores are formed. The FeCu15 sample calcined at $300{ }^{\circ} \mathrm{C}$, with a specific surface area of $124.5 \mathrm{~m}^{2} / \mathrm{g}$, showed the highest catalytic activity $\left(T_{100}=170{ }^{\circ} \mathrm{C}\right.$, Table 1$)$, and the sample calcined at $500^{\circ} \mathrm{C}$ with a specific surface area of

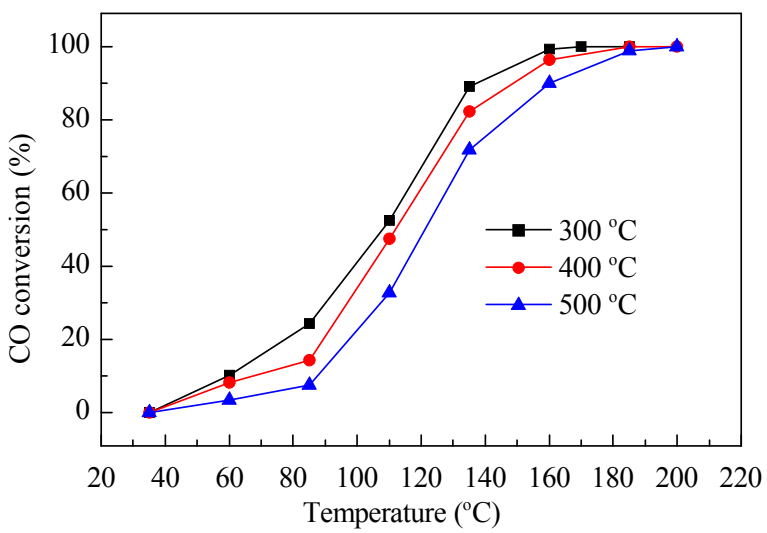

Fig. 10. Catalytic activities in $\mathrm{CO}$ oxidation over FeCu15 sample calcined at 300,400 , and $500^{\circ} \mathrm{C}$; gas hourly space velocity $=60000 \mathrm{~mL} \mathrm{~g}^{-1} \mathrm{~h}^{-1}$.

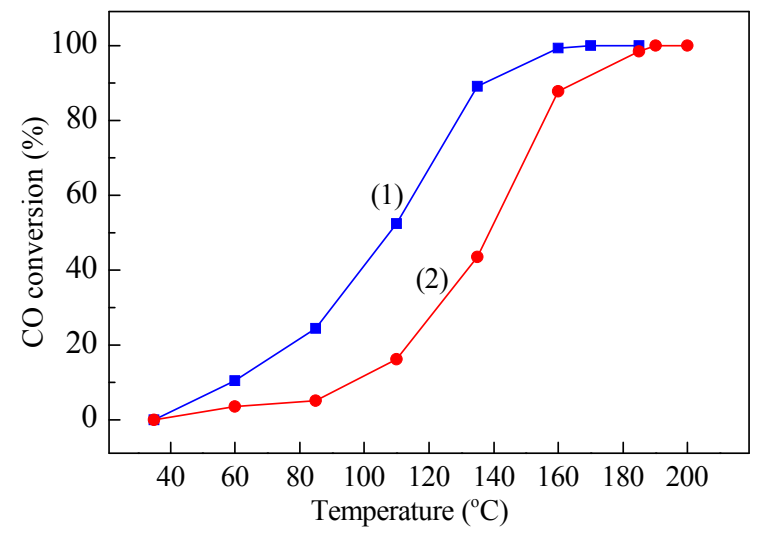

Fig. 11. Catalytic activities of FeCu15 sample prepared in this work (1) and in our previous work (2), both calcined at $300^{\circ} \mathrm{C}$.

$17.9 \mathrm{~m}^{2} / \mathrm{g}$ showed the lowest catalytic activity $\left(T_{100}=200^{\circ} \mathrm{C}\right)$.

Fig. 11 shows the catalytic activity results for the FeCu15 prepared in this work and those for FeCu15 prepared in our previous work [19]. The graphs show that the catalytic activity in low-temperature $\mathrm{CO}$ oxidation of the FeCu15 sample prepared in this work using $\mathrm{Fe}\left(\mathrm{NO}_{3}\right) \cdot 9 \mathrm{H}_{2} \mathrm{O}$ as the Fe precursor is higher than that of the FeCu15 sample prepared in our previous work using $\mathrm{FeCl}_{3} \cdot 6 \mathrm{H}_{2} \mathrm{O}$ as the Fe precursor. $\mathrm{NO}_{3}{ }^{-}$ions are decomposed during calcination and removed from the catalyst surface. In contrast, $\mathrm{Cl}^{-}$ions are not decomposed; they remain on the surface of the catalyst and act as a poison by covering some of the active sites, thereby decreasing catalytic activity.

The catalyst stability and effects of feed composition and reaction time on the catalytic activity of $\mathrm{FeCu} 15$ were investigated by performing the $\mathrm{CO}$ oxidation reaction for various time at $150{ }^{\circ} \mathrm{C}$, using various feed compositions; the results are shown in Fig. 12. The results show that the prepared catalyst had good stability during reaction for $50 \mathrm{~h}$, without any decrease in $\mathrm{CO}$ conversion. Addition of $10 \% \mathrm{CO}_{2}$ to the feed composition caused a small drop in catalytic activity initially, and then the activity remained unchanged for $50 \mathrm{~h}$ on stream. The addition of $10 \% \mathrm{H}_{2} \mathrm{O}$ vapor to the feed composition containing $\mathrm{CO}_{2}$ further reduced the initial catalytic activity, which then remained unchanged for $50 \mathrm{~h}$. The initial decrease in catalytic

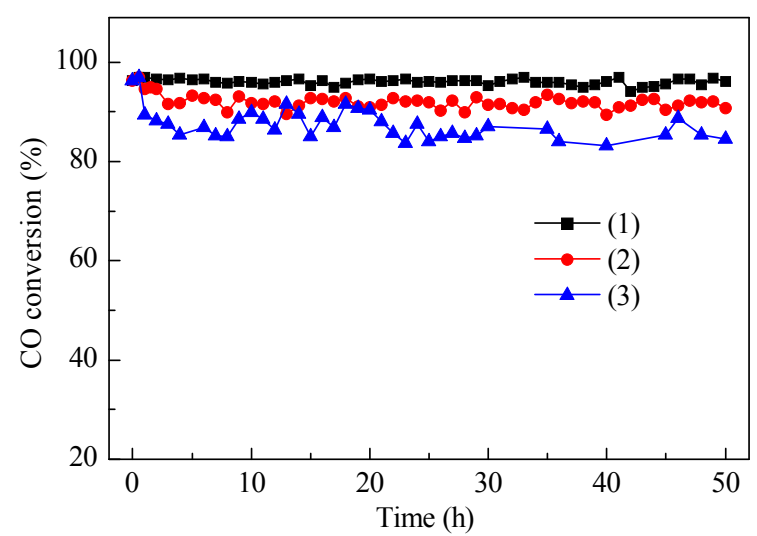

Fig. 12. Long-term stability of FeCu15 catalyst calcined at $300{ }^{\circ} \mathrm{C}$ in the presence of different feed compositions: net feed (1), feed with $10 \%$ $\mathrm{CO}_{2}$ (2), and feed with $10 \% \mathrm{CO}_{2}$ and $10 \% \mathrm{H}_{2} \mathrm{O}$ (3). 
activity can be attributed to the formation of carbonate species on the catalyst surface and the occupation of active sites on the catalyst by $\mathrm{CO}_{2}$ and $\mathrm{H}_{2} \mathrm{O}$ molecules. These results indicate that $\mathrm{Fe}-\mathrm{Cu}$ mixed metal oxide catalysts prepared using a sol-gel method are stable in low-temperature $\mathrm{CO}$ oxidation, even in the presence of deactivating agents such as $\mathrm{H}_{2} \mathrm{O}$ vapor and $\mathrm{CO}_{2}$.

\section{Conclusions}

Mesoporous Fe-Cu mixed metal oxide nanopowders with different $\mathrm{Cu} / \mathrm{Fe}$ molar ratios and high specific surface areas were synthesized via a simple, inexpensive, and surfactant-free sol-gel route, using propylene oxide as the gelation agent. The powders have mesopores with narrow pore size distributions, and nanocrystalline structures with particle sizes in the range 5-15 nm. The results show that the catalytic activity of pure $\mathrm{Fe}_{2} \mathrm{O}_{3}$ in low-temperature $\mathrm{CO}$ oxidation is low, but the addition of $\mathrm{CuO}$ to $\mathrm{Fe}_{2} \mathrm{O}_{3}$ significantly increases the catalytic activity at low temperatures. $\mathrm{CuO}$ and pure $\mathrm{Fe}_{2} \mathrm{O}_{3}$ form $\mathrm{Fe}-\mathrm{Cu}$ mixed metal oxides with high surface areas and increased catalytic activities through a synergistic effect. The FeCu15 sample has the highest surface area and catalytic activity, with complete CO conversion at $170{ }^{\circ} \mathrm{C}$. The results indicate that the prepared catalyst has good stability during reaction for $50 \mathrm{~h}$, without any decrease in $\mathrm{CO}$ conversion. In addition, the $\mathrm{Fe}-\mathrm{Cu}$ mixed metal oxide catalyst prepared via a sol-gel method is stable in low-temperature CO oxidation, even in the presence of deactivating agents such as $\mathrm{H}_{2} \mathrm{O}$ vapor and $\mathrm{CO}_{2}$.

\section{Acknowledgments}

The authors gratefully acknowledge the supports from University of Kashan by Grant No. 158426/13.

\section{References}

[1] Gardner S D, Hoflund G B, Schryer D R, Schryer J, Upchurch B T, Kielin E J. Langmuir, 1991, 7: 2135

[2] Haruta M, Tsubota S, Kobayashi T, Kageyama H, Genet M J, Delmon B. J Catal, 1993, 144: 175

[3] Wang S R, Huang J, Zhao Y Q, Wang S P, Wang X Y, Zhang T Y, Wu S H, Zhang S M, Huang W P.J Mol Catal A, 2006, 259: 245

[4] Schryer D R, Upchurch B T, Sidney B D, Brown K G, Hoflund G B, Herz R K. J Catal, 1991, 130: 314

[5] Schryer D R, Upchurch B T, Van Norman J D, Brown K G, Schryer J. J Catal, 1990, 122: 193

[6] Han Y F, Kahlich M J, Kinne M, Behm R J. Appl Catal B, 2004, 50: 209

[7] Zhu H Q, Qin Z F, Shan W J, Shen W J, Wang J G. J Catal, 2004, 225 : 267

[8] Cao J L, Wang Y, Yu X L, Wang S R, Wu S H, Yuan Z Y. Appl Catal B, 2008, 79: 26

[9] Cheng T, Fang Z Y, Hu Q X, Han K D, Yang X Z, Zhang Y J. Catal Commun, 2007, 8: 1167

[10] Cao J L, Shao G S, Wang Y, Liu Y P, Yuan Z Y. Catal Commun, 2008, 9: 2555

[11] Biabani-Ravandi A, Rezaei M. Chem Eng J, 2012, 184: 141

[12] Guo Q, Liu Y. Appl Catal B, 2008, 82: 19

[13] Sadeghinia M, Rezaei M, Amini E. Korean J Chem Eng, 2013, 30: 2012

[14] Li J, Zhu P F, Zuo S F, Huang Q Q, Zhou R X. Appl Catal A, 2010, 381: 261

[15] Li G N, Li L, Shi J J, Yuan Y Y, Li Y S, Zhao W R, Shi J L.J Mol Catal A, 2014, 390: 97

[16] Li G N, Li L, Li Y S, Shi J L. New J Chem, 2015, 39: 1742

[17] Kuhn J N, Tsung C K, Huang W Y, Somorjai G A. J Catal, 2009, 265: 209

[18] Borodko Y, Jones L, Lee H, Frei H, Somorjai G. Langmuir, 2009, 25: 6665

\section{Graphical Abstract}

Chin. J. Catal., 2015, 36: 1711-1718 doi: 10.1016/S1872-2067(15)60922-6

Preparation of mesoporous Fe-Cu mixed metal oxide nanopowder as active and stable catalyst for low-temperature CO oxidation

Ehsan Amini, Mehran Rezaei *

University of Kashan, Iran
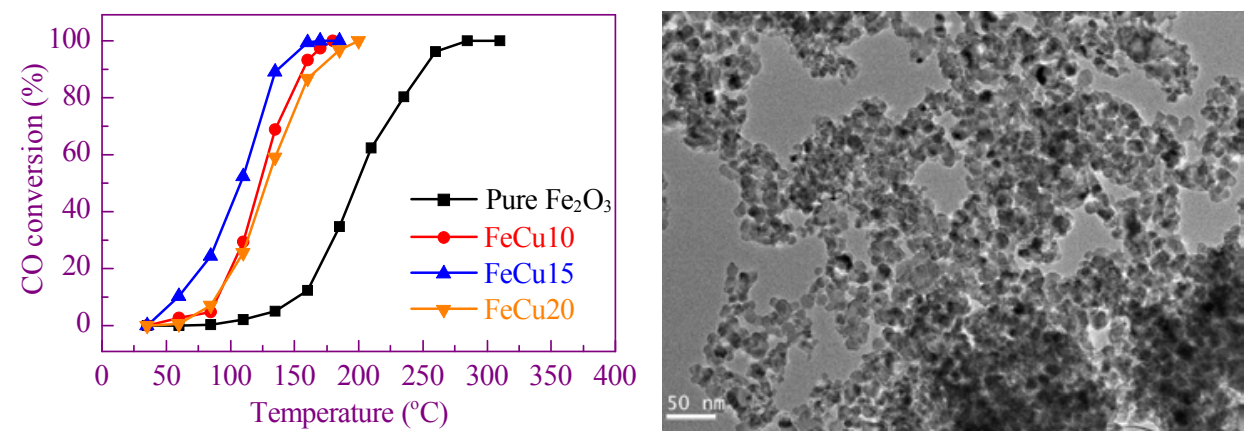

Mesoporous $\mathrm{Fe}-\mathrm{Cu}$ mixed metal oxide nanopowders with different $\mathrm{Cu} / \mathrm{Fe}$ molar ratios and high specific surface areas were synthesized via a sol-gel route. The nanopowders exhibited good catalytic behavior in low-temperature CO oxidation. 
[19] Amini E, Rezaei M, Sadeghinia M. Chin J Catal (催化学报), 2013, 34: 1762

[20] Yentekakis I V, Lambert R M, Konsolakis M, Kallithrakas-Kontos N. Catal Lett, 2002, 81: 181
[21] Yang Q J, Choi H, Al-Abed S R, Sionysios D D. Appl Catal B, 2009, 88: 462

[22] Fierro G, Lojacono M, Inversi M, Porta P, Lavecchia R, Cioci F. J Catal, 1994, 48: 709

\section{介孔 $\mathrm{Fe}-\mathrm{Cu}$ 复合金属氧化物纳米粉催化剂催化低温 $\mathrm{CO}$ 氧化 \\ Ehsan Amini, Mehran Rezaei * \\ 喀山大学纳米科技研究所, 工程学院化工系催化剂与先进材料研究实验室, 喀山, 伊朗}

摘要: 以环氧丙烷为凝胶剂, 采用简便低廉的无表面活性剂的溶胶-凝胶法制备了一系列不同 $\mathrm{Cu} / \mathrm{Fe}$ 摩尔比的高比表面积介孔 $\mathrm{Fe}-\mathrm{Cu}$ 复合氧化物纳米粉末. 运用微反应器-色谱体系考察了它们在低温 $\mathrm{CO}$ 氧化反应中的催化性能. 采用X射线衍射、 $\mathrm{N}_{2}$ 吸附-脱 附、热重-差热分析、程序升温还原、傅里叶变换红外光谱和透射电镜对所制样品进行了表征. 结果表明, 这些介孔Fe-Cu复合氧 化物催化剂具有纳米晶结构、窄的孔径分布和高的比表面积, 在低温 $\mathrm{CO}$ 氧化反应中表现出高的活性和稳定性. $\mathrm{CuO}$ 的添加影响了 $\mathrm{Fe}_{2} \mathrm{O}_{3}$ 的结构和催化性能. 当 $\mathrm{CuO}$ 含量为 $15 \mathrm{~mol} \%$ 时, 催化剂具有最高的比表面积和催化活性, 在低温 $\mathrm{CO}$ 氧化反应中表现出较高的 催化稳定性.

关键词: 氧化铁; 氧化铜; 金属氧化物催化剂; 介孔纳米粉;一氧化碳氧化; 溶胶凝胶法

收稿日期: 2015-04-13. 接受日期: 2015-05-25. 出版日期: 2015-10-20.

*通讯联系人. 电话: +98-31-55912469; 传真: +98-31-55559930; 电子信箱: rezaei@kashanu.ac.ir

本文的英文电子版由Elsevier出版社在ScienceDirect上出版(http://www.sciencedirect.com/science/journal/18722067). 